\title{
МОВНЕ ВИРАЖЕННЯ КОНЦЕПТУ СЛОВО В ПОЕЗІЇ С. САПЕЛЯКА
}

Тема слова належить до традииійних у поезії, проте і до сьогодні не втрачає своєї важливості. Трансиендентна сутність слова знаходить своє вираження і на мовному полотні поезій С. Сапеляка. У статті здійснено спробу дослідити особливості мовного вираження кониепту СЛОВО в поетичних текстах С. Сапеляка. Сьогодні творчість иього поета в аспекті мовознавства залишається малодослідженою, що зумовлює актуальність статті. Мовно-поетична картина світу С. Сапеляка наповнена образами слова, мовне вираження якого й стало предметом нашого дослідження.

Ключові слова: концепт, мовна картина світу, лексема, слово

\section{Skydan Ya. A. Language Expression of the Concept WORD in the Poetry} by S. Sapeliak. The word is one of polysemantic linguistic concepts and in linguistic science is a significant unit of language and form of human existence. Modern world and national linguistics actively uses the notion of 'concept' as information about a unit of memory and sum total of knowledge about the object of cognition. The language picture of the world comprises of concepts which in turn include smaller semantic units, namely images. The topic of word is traditional in poetry, but still does not lose its relevance. The transcendental essence of a word is also reflected in the language of S. Sapeliak's poetry. This article focuses on the study and analysis of peculiarities of lingual expression of the concept WORD in poetic texts by S. Sapeliak. The poetic picture of the world of S. Sapeliak is filled with images of word, whose lingual expression has become the subject of our research. The basis of the study are the poems by S. Sapeliak. The research is relevant due to insufficient research on the concept WORD in the poet's work. The purpose of the article is to analyse the artistic and semantic content of the concept WORD. In his creative work S. Sapeliak often refers to the lexeme WORD, the figurative expression of which in different texts, though has common features, is constantly changing and gaining new meanings. In the linguistic design of the poetic text, the word is verbalized by lexemes of sound and voice, mother and Ukraine. The linguistic expression of the concept WORD is embodied in new poetic images and is conveyed through the use of artistic means such as metaphor and artistic meaning, or epithet. Thus, the linguistic expression of the concept WORD in S. Sapeliak's creative work is often used and metaphorized, which enables the author to create an individual poetic picture of the world in which the word becomes both the subject of the portrayal and its means.

Key words: concept, languagec picture of the world, lexeme, word. 


\section{Вступ}

Поезія давно вже стала об’єктом наукових праць і досліджень багатьох вітчизняних і зарубіжних мовознавців, серед яких можна згадати О. О. Потебню, Р. Й. Якобсона, М. М. Бахтіна, В. В. Виноградова, Д. С. Лихачова, В. С. Калашника, Л. О. Ставицьку та багатьох інших. Проте й зараз ця галузь $є$ не достатньо вивченою, тому продовжує цікавити науковців.

У цій розвідці здійснено спробу з'ясувати, за допомогою яких мовних засобів знаходить своє вираження концепт слово в поетичних текстах С. Сапеляка. На сьогодні творчість цього поета з погляду мовознавства залишається малодослідженою, що зумовлює актуальність поданої розвідки. Мета статті - дослідити особливості мовного вираження концепту слово у віршах С. Сапеляка на матеріалі кількох збірок автора. Завдання статті - проаналізувати художньо-смислове наповнення концепту слово.

\section{Методи та методики дослідження}

Досягнення поставленої мети та зазначених завдань досягається шляхом застосування описово-аналітичного та семантико-стилістичного методів наукового дослідження. Для роботи було виділено й проаналізовано чотири збірки С. Сапеляка, у яких відібрано понад сімдесят поетичних контекстів із використанням концепту слово.

\section{Результати та дискусії}

Споконвіку було Слово, а Слово в Бога було, і Бог було Слово... так починається Євангеліє від св. Івана в перекладі професора I. Огієнка. Як відомо, слово як таке здавна було невід'ємним й важливим складником розвитку людства, бо слугувало виразником почуттів і репрезентантом думок. Саме слово дало людині можливість оволодіти мовою й таким чином стати на найвищій сходинці біологічних видів на планеті. 3 прадавніх часів слову приділяли особливу увагу, його вважали священним, а під впливом візантійської богословської традиції слово набувало сакрального значення не лише в Біблії, й у творах усної народної творчості.

Відомий лінгвіст О. Потебня стверджував, що майже все питоме в мові - це плоди міфічного мислення, тобто мислення донаукового, яке стало передосновою мислення поетичного, що виокремлює, 
у свою чергу, мислення наукове, бо передбачає вже аналіз і синтез (Потебня, 1976: 420). Адже ніщо інше, як слово, є найбільш явним для свідомості показником здійснення акту пізнання (Потебня, 1976: 446), оскільки саме слово як найменша одиниця мови $€$ інструментом людського світосприйняття й світовідтворення. У свою чергу, мова, за словами Г. Лейбніца, - це дзеркало людського духу, тобто засіб відображення не лише зовнішніх реалій, але й засіб споглядання нашого внутрішнього.

Усе те, що йде від людини, плід іiі сприйняття, фантазій, мисленнєвих процесів і перетворювальної діяльності створює іiі так звану картину світу. Разом із тим світ - це й сама людина, коли йдеться про іiі внутрішні світовідчуття, переживання, розумову діяльність, невіддільну від мови як способу організації інформації про сам світ, а ширше - всесвіт. Всесвіт як всеохопний світ є для людини всеосяжним предметом пізнання. Тому феномен світу, пізнаного через мову, постає для людини передусім таким, яким постає для неї їі мова (Косенко, 2012).

Мова - специфічне суспільне явище, що має зміст і форму й у своєму виникненні та розвитку тісно пов'язане з матеріальним і духовним життям народу. Мова - найважливіший комунікативний засіб людини, який забезпечує також пізнавальну функцію та розвиток іiі мислення, зумовлюючи тим самим безперервний розвиток суспільства.

Усі слова, якими користуються люди, входять до лексичного, або словникового, складу мови, де вони живуть і розвиваються за своїми внутрішніми законами. Народ $є$ як носієм, так і творцем мови. Найактивніше до цього процесу звертаються у своїх творах прозаїки й поети. У мовознавчій науці слово $є$ значущою одиницею мови і формою людського існування. Крім того, слово - один із багатозначних мовних концептів.

Сучасна світова й вітчизняна лінгвістика активно послуговується поняттям «концепт» як інформаційною одиницею пам'яті й сукупністю знань про об’єкт пізнання. Певна річ, це безпосередньо пов'язано з функціонуванням мови в художній творчості. Такі типи концептів, як уявлення, узагальнені чуттєвонаочні образи (за способом концептуалізації), ідіоконцепти (за параметром суб'єкта концептуалізаціiі), образно-художні (за якістю інформації), культурні та емоційні 
(за параметром об’єкта концептуалізації), які виділяє Олена Селіванова (Селіванова, 2006: 258), безпосередньо пов'язані з мовою поезіі. Концептуалізація художнього світу поета як творчої особистості знаходить вияв у мовній картині світу, в образно-поетичному іiі фрагменті.

Мовна картина світу складається із концептів, куди у свою чергу входять менші семантичні одиниці - образи. Ці образи можуть бути архетипними, національними або індивідуальними (Косенко, 2012: 6-10). У віршовій мові вживане поетом слово трансформується, набуває естетичних якостей і стає конструктивним елементом художнього змісту. При цьому поетичне слово має лише слабкий ореол зв'язаності з денотативним позамовним простором (Ревизина, 1990: 34).

Тема слова належить до традиційних у поезії. По-різному й різною мірою ця вічна тема надихає поетів до творчості. Не обійшов її своєю увагою й український поет-дисидент, лауреат Шевченківської премії Степан Сапеляк. Одна із прижиттєвих збірок поета має промовисту назву - «Во ім'я Слова», у ній автор роздумує про вагу слова. Слова будителя. Слова сакрального. Слова як вищого Дару Божого (Сапеляк, 2007). У своїй творчості С. Сапеляк часто звертається до лексеми слово, образне вираження якої в різних текстах хоч і має спільні ознаки, проте постійно видозмінюється й набуває дедалі нових значень. Наприклад, в одному з давно написаних творів, елегійному вірші «Невольнича рапсодія», слово для поета стає символом порятунку у світі, де панує несвобода і зло: Святеє слово. Ноїв мій ковчег (Сапеляк, 2001: 81), а в деяких інших творах (зокрема в останній прижиттєвій збірці «Незів'яле листя») - символом достатку й насолоди: в слові купалися (Сапеляк, 2011: 130), духовною їжею: Слово - хлібино моя (Сапеляк, 2011: 148), зброєю: Слово - звитяжний мій меч (Сапеляк, 2011: 149).

Узагалі, слово для С. Сапеляка - це щось величне, вічне й сакральне. 3 одного боку, воно ставало ретранслятором інтимних переживань, життєвих радощів і болів, які знаходили вихід через поетичне слово: виспівую... словом сумління (Сапеляк, 2017: 69) або слово моє... рапсодія болю (Сапеляк, 2017: 34). 3 іншого боку, слово для поета було нерозривно пов'язане з образами-символами матері, Батьківщини і свободи: Слово - хлібино моя / і Покрово Мови моєї.../ Мово - свободо моя українна... (Сапеляк, 2011: 148) або Слово моє / Дніпре мій (Сапеляк, 2011: 148). 
У мовному полотні поезій С. Сапеляка відбито біографічні елементи автора, який протягом свого тяжкого, сповненого зухвалої боротьби життя, ідучи під гаслом Караюсь, мучусь, але не каюсь... (Сапеляк, 2017: 103), майстерно витворював Літопис слова (Сапеляк, 2001: 135) i, не падаючи духом, виконував життєствердну пісню, яку в слові поцілував (Сапеляк, 2011: 124).

У своїй поезії С. Сапеляк, використовуючи архетипний образ слова, немовби наслідує традиції Тараса Шевченка із його я на сторожі... поставлю слово і продовжує ідеї Лесі Українки, у якої Слово, моя ти єдиная зброє. Слово для С. Сапеляка - то звитяжний... меч (Сапеляк, 2011: 149), яким, наче Франкове словом сильним, мов трубою, поет веде боротьбу із несправедливістю світу.

Сила слова не завжди вловима і відчутна, проте завдяки своїй трансцендентній сутності слово ніколи не минає намарне і набуває ознак божественності й усевладності. Непроминальним стало воно й для С. Сапеляка, який усе життя служив слову і шанував його. Поет іще $з$ дитячих літ прийняв віру, а з вірою прийшло Слово, оте, яке було в Бога і яке було Бог. I наче підтверджуючи істинність сказаного в Бібліі, автор погоджується, що найперше було слово (Сапеляк, 2017: 50), проте не зупиняється на цьому, а подає власну інтерпретацію Слова Божого, додаючи, що створилося Слово Українське (Сапеляк, 2017: 50). Таким чином автор ніби утверджує безсмертя й слова українського, і народу.

Про важливість слова говорив чи не кожен поет, закликаючи до його пізнання, бо, як писала Л. Костенко, лиш народи, явлені у слові, достойно жити можуть на землі. Не винятком стала й поезія С. Сапеляка, у мовотворчості якого концепт слово репрезентовано в метафорі через поєднання з іменниками та з художніми означеннями: слова німі (Сапеляк, 2001: 238), слів сумне сапеляків'я (Сапеляк, 2011: 144), Слів бездітне чекання (Сапеляк, 2001: 58), словом понівеченим (Сапеляк, 2017: 49), в золищі слова (Сапеляк, 2007: 29), слово моє... хай... множиться (Сапеляк, 2011: 170).

Через метафоризацію слово часто набуває значення локації, середовища, та й сам поет ніби знаходиться в просторі слова (Сапеляк, 2017: 50): і закувала зозуленька / на все слово світом (Сапеляк, 2017: 34), князі... полем слово городили (Сапеляк, 2011: 130), в слові купалися (Сапеляк, 2011: 130). 
У мовному оформленні поетичного тексту автор персоніфікує слово, створюючи то тихе, то гучне багатоголосся: один-однісінький звук / многоголосо серед янголяточок слова / тихне (Сапеляк, 2017: 100), зникає глас трипільських лун, / і скрині слів гукають з'яву (Сапеляк, 2017: 55), в просторі слова і в голосі тіла (Сапеляк, 2017: 50), сказало собі слово (Сапеляк, 2017: 146). Озвучення, виголошення, промовляння слова створює нові образи, а використання зменшено-пестливих форм (однісінький, янголяточок) чи старослов'янізмів (глас) викликає емоції замилування або величності відповідно.

Узявши за основу традиції Святого Письма й народної поезії, автор подає власне бачення образу слова: слово моє многодумне... хай... множиться (Сапеляк, 2011: 170), а за допомогою прийомів словотвору вибудовує оказіоналізми, щоб яскравіше й глибше зобразити свій внутрішній стан: слів сумне сапеляків'я (Сапеляк, 2011: 144).

\section{Висновки}

Отже, концепт слово в художніх творах С. Сапеляка знаходить вираження через метафору, що досягається передусім використанням засобів переносного значення (персоніфікація, символіка). Це дає авторові змогу створити індивідуальну поетичну картину світу, у якій слово стає і предметом зображення, і його способом. У мовному оформленні поетичного тексту художньо-смислове наповнення концепту відбувається шляхом його вербалізації різноманітними лексемами й за допомого використання метафори й художнього означення.

\section{ЛIТЕРАТУРА}

1. Калашник В. С. Людина та образ у світі мови: вибрані статті. Харків: ХНУ ім. В. Н. Каразіна, 2011. 368 с. 2. Косенко О. С. Мовна картина світу. Філософія: збірник праць. Київ, 2012. URL: http://www.info-library.com.ua/books-book-204.html. 3. Лисиченко Л. А. Мовна картина світу та ії рівні. Вісник Харк. іст.-філ-го тов-ва. 1998. № 6. С. 6-10. 4. Потебня А. А. Эстетика и поэтика. Москва, 1976. 614 с. 5. Ревзина О. Г. От стихотворной речи к поэтическому идиолекту. Очерки истории языка русской поэзии ХХ в.: Поэтический язык и идиостиль. Москва, 1990. С. 39-46. 6. Селіванова О. О. Сучасна лінгвістика: Термінологічна енциклопедія. Полтава: Довкілля-К, 2006. 716 с.

\section{ДЖЕРЕЛА}

1. Сапеляк Степан. Вибране. Тернопіль: Терно-граф, 2017. 176 с. 2. Сапеляк Степан. Во ім'я Слова. Харків: Майдан, 2007. 152 с. 3. Сапеляк Степан. I каміння те стало хлібами...: у 3 т. Харків: Майдан, 2001. Т. 1: Поезії. 336 с. 4. Сапеляк Степан. Незів’яле листя. Харків: Майдан, 2011. 240 с. 


\section{REFERENCES}

1. Kalashnyk, V. S. (2011). Lyudyna ta obraz u sviti movy: vybrani statti [Man and image in the world of languages: selected articles]. Kharkiv: KhNU im. V. N. Karazina [in Ukrainian]. 2. Kosenko, O. S. (2012). Movna kartyna svitu [The linguistic picture of the world]. Filosofia: zbirnyk prats - Filosofiia: Collection of works. Retrieved from http://www. info-library.com.ua/books-book-204.html [in Ukrainian]. 3. Lysychenko, L. A. (1998). Movna kartyna svitu ta yiyi rivni. [The linguistic picture of the world and its levels]. Visnyk Khark. ist.-fil-ho tov-va - Bulletin of the Kharkiv Historical and Philological Society, 6, 6-10 [in Ukrainian]. 4. Potebnya, A. A. (1976). Estetyka y poetyka. [Aesthetics and poetics]. Moskva [in Russian]. 5. Revzyna, O. H. (1990). Ot stykhotvornoy rechy $k$ poetycheskomu ydyolektu. Ocherky ystoryy yazyka russkoy poezyy XX v.: Poetycheskyy yazyk y ydyostyl. [From poetic speech to a poetic idiolect. Essays on the history of the language of Russian poetry of the 20th century: Poetic language and idiostyle]. (pp. 39-46). Moskva [in Russian]. 6. Selivanova, O. O. (2006). Suchasna linhvistyka: Terminolohichna entsyklopediya. [Modern linguistics: A terminological encyclopedia]. Poltava: Dovkillya-K [in Ukrainian].

\section{SOURCES}

1. Sapelyak, Stepan. (2017) Vybrane. [Favorites]. Ternopil: Terno-hraf [in Ukrainian]. 2. Sapelyak, Stepan. (2007). Vo imya Slova. [In the name of the Word]. Kharkiv: Maydan [in Ukrainian]. 3. Sapelyak, Stepan. (2001). I kaminnya te stalo khlibamy... [And the stones became bread...]. (Vol. 1: Poetry). Kharkiv: Maydan [in Ukrainian]. 4. Sapelyak, Stepan. (2001). Nezivyale lystya. [Not withered leaves]. Kharkiv: Maydan [in Ukrainian].

Скидан Ярослав Анатолійович - аспірант кафедри української мови, Харківський національний педагогічний університет імені Г. С. Сковороди. Вул. Валентинівська, 2, Харків, 61168, Україна.

Tel.: +38-063-577-69-90

E-mail: yaskidan@ukr.net

https://orcid.org/0000-0002-1263-9800

Skydan Yaroslav Anatoliiovych - Postgraduate Student, Ukrainian Language Department, H.S. Skovoroda Kharkiv National Pedagogical University. Valentynivska Str., 2, Kharkiv, 61168, Ukraine. 